\title{
Applicability of carbothermic reduction for upgrading Sri Lankan ilmenite ores: towards converting ilmenite into synthetic rutile by mechanical activation
}

\author{
T. Dilmi. U. Wijewardhana and Amila Sandaruwan Ratnayake* (1)
}

\begin{abstract}
Background: Ilmenite and rutile are naturally occurring titanium-bearing heavy minerals. Sri Lanka consists of ilmenite and rutile in placer deposits mainly along the northeast coast. The commercial value of rutile is higher than ilmenite. Therefore, the current study focuses to upgrade Sri Lankan ilmenite ores using commercially available activated carbon as a reducing agent. IImenite fraction was initially separated from raw beach sand using an industrialscale magnetic separator (Wet high-intensity magnetic separator: sixteen pole model). The mixtures of ilmenite and activated carbon (4 to 1 ratio by weight) were milled using a planetary ball mill for one to four hours at one-hour intervals.
\end{abstract}

Results: The milled samples were subsequently heated for two hours continuously at temperatures of $800{ }^{\circ} \mathrm{C}, 900{ }^{\circ} \mathrm{C}$, $1000^{\circ} \mathrm{C}, 1100^{\circ} \mathrm{C}$, and $1200^{\circ} \mathrm{C}$, respectively. Initial and annealed samples were analysed using X-ray diffraction (XRD), Fourier-transform infrared (FTIR) spectroscopy, and X-ray fluorescence (XRF) analyses. XRD pattern of the initial sample was characterized by less percentage of rutile $\left(\mathrm{TiO}_{2}\right)$ peaks and low crystallinity. However, the number of rutile peaks and crystallinity were increased with respective milling hours and annealed temperature. Besides, XRD analysis indicates a higher number of sharp and intense rutile and elemental iron peaks in the samples annealed above $1000^{\circ} \mathrm{C}$. FTIR analysis of raw ilmenite indicates mainly stretching vibrations of Fe-O. However, vibrational spectral bands around $700 \mathrm{~cm}^{-1}$ in samples annealed above $1000^{\circ} \mathrm{C}$ are assigned to Ti-O-Ti stretching vibrations. $\mathrm{High} \mathrm{TiO}_{2}$ and $\mathrm{TiO}_{2}+\mathrm{Fe}_{2} \mathrm{O}_{3}$ (total) wt. (\%) can also be observed in samples annealed above $1000^{\circ} \mathrm{C}$.

Conclusions: The optimum conditions for carbothermic reduction were obtained at $4 \mathrm{~h}$ of ball milling of ilmenite with activated carbon and continuously annealing at $1000^{\circ} \mathrm{C}$ for $2 \mathrm{~h}$. Carbothermic reduction is applicable to upgrade Sri Lankan ilmenite ores, and thus this method adds value to heavy mineral resources in Sri Lanka.

Keywords: Heavy minerals, Sri Lanka, Ilmenite, Synthetic rutile, Value addition, Carbothermic reduction

\section{Background}

Ilmenite $\left(\mathrm{FeTiO}_{3}\right)$ (approximately, 40-60\% of $\mathrm{TiO}_{2}$ ), rutile $\left(\mathrm{TiO}_{2}\right)\left(\sim 93-96 \%\right.$ of $\left.\mathrm{TiO}_{2}\right)$ and leucoxene $\left(\mathrm{Fe}_{2} \mathrm{O}_{3}\right.$. $\left.n \mathrm{niO}_{2}\right)\left(\sim\right.$ over $65 \%$ of $\left.\mathrm{TiO}_{2}\right)$ are the major ores of metal

*Correspondence: as_ratnayake@uwu.ac.Ik

Faculty of Applied Sciences, Uva Wellassa University, Passara Road, Badulla 90000, Sri Lanka titanium and titanium dioxide (Wouterlood 1979; Ismail et al. 1983; Chen et al. 1997; Angusamy et al. 2005; Palliyaguru et al. 2017; Perks and Mudd 2019, 2020, 2021). Both ilmenite and rutile are usually mined from beach placer deposits. Titanium minerals characterise by properties such as exceptional scattering, chemical stability, and lack of toxicity (Adipuri et al. 2011). Titanium alloys are used in aerospace, biomedical, automotive and metallurgical industries, and titanium dioxide is used in paint, 
paper, pigments and plastic industries. Consequently, titanium minerals have become a valuable commodity (Adipuri et al. 2011; Perks and Mudd 2019). Because of that, a large number of high-quality titanium ores such as rutile are required for catering to the escalating global demands of both metal titanium and $\mathrm{TiO}_{2}$ based products, especially in the Asia-Pacific region (Mackey 1994; Dooley 1975; Wang et al. 2008). In this case, the production of synthetic rutile $\left(\mathrm{TiO}_{2}\right)$ is gradually increasing due to a dearth of economically concentrated rutile deposits in the world. For example, ilmenite accounts for $94 \%$ of global titanium resources, while that of rutile is only about $4 \%$, and the rest being supplied by minerals such as leucoxene (Perks and Mudd 2020, 2021). Therefore, much attention has been taken to process low-grade titanium ores such as ilmenite (approximately US\$ 130 per tonne in 2019) into synthetic rutile (approximately US\$ 1150 per tonne in 2019) (Subasinghe et al. 2021). About $5 \%$ of the mined ilmenite is generally used to produce titanium metal while the rest is used in the production of titanium dioxide/synthetic rutile (Zhang et al. 2011; Perks and Mudd 2020, 2021). Consequently, readily available ilmenite gradually became an alternative raw material for synthetic rutile (Chen et al. 1997; Wang and Yuan 2006; Wang et al. 2008).

Several methods have been investigated in the literature to upgrade ilmenite into synthetic rutile such as smelting (Murty et al. 2007), acid leaching (Mahmoud et al. 2004), ion-exchange (Palliyaguru et al. 2017), sulphation (Lee and Sohn 1989; Nurdin et al. 2019), selective chlorination (Neurgaonkar et al. 1986; Rhee and Sohn 1990), reduction (Shiah 1978; Kahn 1984; Wijewardhana et al. 2021), and slagging (Wright et al. 1985). In addition, certain industrial-scale limitations and environmentally unfriendly waste generation (e.g., usage of corrosive and hazardous chemicals) make the existing processes expensive and problematic. For example, the sulphate process generates 3.5 tonnes of waste, while the chloride process generates only 0.2 tonnes of waste, per tonne of $\mathrm{TiO}_{2}$ product (Mackey 1994). Although the chloride method limits waste generation, this method requires high titanium content in the feedstock to reduce the processing time (Tao et al. 2012). Despite these limitations and drawbacks, Sri Lankan ilmenite ores have not been the focus of value addition at an industrial scale using any of the methods stated in the literature (Subasinghe et al. 2021)

The current study thus focuses to apply a modified ball milling induced carbothermic reduction using commercially available activated carbon as an additive. In this study, the authors determine the optimum conditions of the reaction based on geochemical changes and crystallinity in milled and annealed samples using X-ray powder diffraction (XRD), Fourier transform infrared (FTIR), and $\mathrm{X}$-ray fluorescence (XRF) analyses. The current study examines the value addition potential of Sri Lankan ilmenite at the laboratory scale. Consequently, this case study is a timely requirement to upgrade mineral sands in the country for gaining economic benefits. Moreover, determining the industrial viability of this methodology via a pilot plant would be a potential future work.

\section{Study area}

The coastal tract of Sri Lanka consists of several heavy mineral placer deposits (Geological Survey of Ceylon 1970; Herath 1980; Wickremeratne 1986; Subasinghe et al. 2021). For example, Pulmoddai deposit spreads nearly $8 \mathrm{~km}$ from Arisimale to Kokkilai along the northeast coast of Sri Lanka with an average thickness of $6 \mathrm{~m}$ over Precambrian crystalline rocks (Fig. 1). Pulmoddai beach has been commercially exploited since 1957 (Herath 1980). The Pulmoddai deposit records high-grade values of heavy minerals such as $70-72 \%$ of ilmenite, $8-10 \%$ of zircon, $8 \%$ of rutile, $1 \%$ of sillimanite, and $0.3 \%$ of monazite (Sri Lanka Minerals Year Book 2014). This deposit contains nearly 6 million tonnes of heavy mineral sands, and the annual partial replenishment during the northeast monsoon makes this deposit more valuable (Sri Lanka Minerals Year Book 2014; Amalan et al. 2018). In 2015, Sri Lanka exported nearly 39,000 tonnes of ilmenite, 1,800 tonnes of rutile, and 600 tonnes of zircon (Lanka Mineral Sands Ltd 2018; Subasinghe et al. 2021). Two heavy mineral deposits are located towards the north (i.e., Nilaveli to Mulativu beach placer deposits) and south (i.e., Verugal deposit) of the Trincomalee Bay (Fig. 1). These deposits in combination can be considered as one of the largest heavy mineral deposits in the world. The current estimations suggest the availability of about 12.5 million tonnes of unexploited mineral sands in these deposits (Sri Lanka Minerals Year Book 2014).

\section{Methods \\ Materials}

In this study, ilmenite samples were collected from Lanka Mineral Sands Limited, Pulmoddai. Raw beach sands were subjected to screening for the removal of roots, stones, and shells. Screened raw beach sands were separated using spiral separation (Mark-6 Reichert and Mark-3A Reichert Spirals) to remove quartz. Ilmenite was separated using a high-intensity magnetic separator (Wet high-intensity magnetic separator: sixteen pole model) based on its paramagnetic property. Therefore, industrial-scale separated ilmenite ores were used for the geochemical analysis described here. In addition, commercially available activated carbon was used as an 


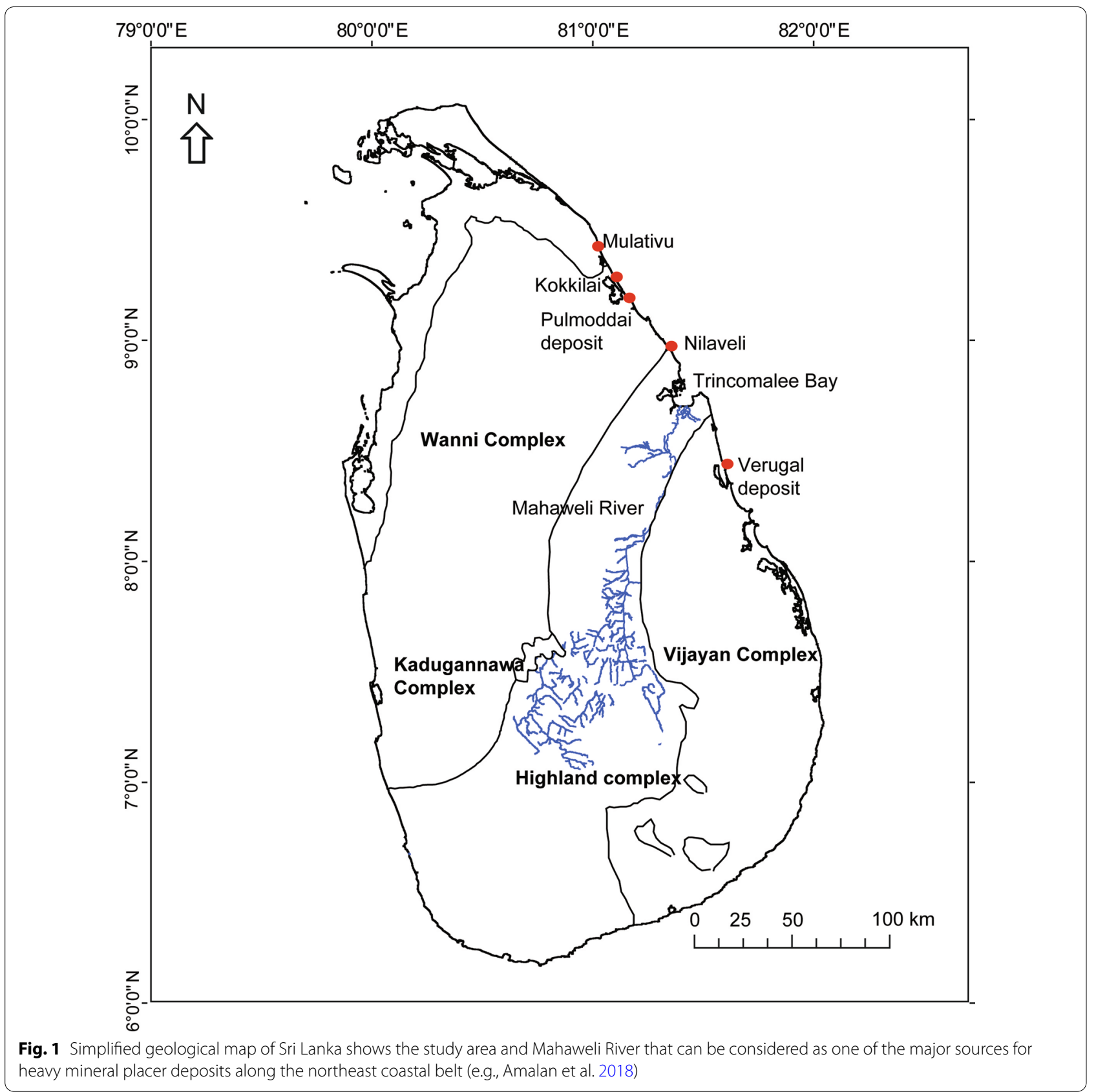

additive (reductant) which is composed of over $95 \%$ of carbon.

\section{Sample preparation}

In this study, $10 \mathrm{~g}$ of ilmenite sand and $2.5 \mathrm{~g}$ of commercially available activated carbon were weighed and mixed thoroughly for the optimum weight ratio (Shahien et al. 2015; Wijewardhana et al. 2021). After that, twenty powdered samples were grouped considering different milling hours and annealed temperatures (Table 1). Samples
Table 1 Labelling of samples based on different milling hours and annealed temperature

\begin{tabular}{lllll}
\hline $\begin{array}{l}\text { Annealed } \\
\text { temperature }\left({ }^{\circ} \mathbf{C}\right)\end{array}$ & \multicolumn{4}{l}{ Milling hours } \\
\cline { 2 - 5 } & $\mathbf{1 h}$ & $\mathbf{2} \mathbf{h}$ & $\mathbf{3} \mathbf{h}$ & $\mathbf{4 h}$ \\
\hline $1200^{\circ} \mathrm{C}$ & $\mathrm{M} 1 / 1200$ & $\mathrm{M} 2 / 1200$ & $\mathrm{M} 3 / 1200$ & $\mathrm{M} 4 / 1200$ \\
$1100^{\circ} \mathrm{C}$ & $\mathrm{M} 1 / 1100$ & $\mathrm{M} 2 / 1100$ & $\mathrm{M} 3 / 1100$ & $\mathrm{M} 4 / 1100$ \\
$1000^{\circ} \mathrm{C}$ & $\mathrm{M} 1 / 1000$ & $\mathrm{M} 2 / 1000$ & $\mathrm{M} 3 / 1000$ & $\mathrm{M} 4 / 1000$ \\
$900^{\circ} \mathrm{C}$ & $\mathrm{M} 1 / 900$ & $\mathrm{M} 2 / 900$ & $\mathrm{M} 3 / 900$ & $\mathrm{M} 4 / 900$ \\
$800^{\circ} \mathrm{C}$ & $\mathrm{M} 1 / 800$ & $\mathrm{M} 2 / 800$ & $\mathrm{M} 3 / 800$ & $\mathrm{M} 4 / 800$ \\
\hline
\end{tabular}


were initially milled for $1 \mathrm{~h}, 2 \mathrm{~h}, 3 \mathrm{~h}$, and $4 \mathrm{~h}$, respectively. Mechanical attrition was performed in a vertical laboratory planetary ball mill (semi-circle model) under an airtight state equipped with a ball mill tank with 1-30 mm zirconium balls and $100 \mathrm{ml}$ zirconium jars. The cell was loaded with mixed samples and milled at room temperature $\left(27^{\circ} \mathrm{C}\right)$ at $500 \mathrm{rpm}$. The milled samples from 1 to $4 \mathrm{~h}$ with 1 -h intervals were continuously annealed at $800{ }^{\circ} \mathrm{C}$, $900{ }^{\circ} \mathrm{C}, 1000{ }^{\circ} \mathrm{C}, 1100{ }^{\circ} \mathrm{C}$, and $1200{ }^{\circ} \mathrm{C}$, separately for $2 \mathrm{~h}$ using a muffle furnace as shown in Table 1.

\section{Particle size analysis}

The particle size distribution of the initial ilmenite and four hours milled samples were analysed using a British standard mechanical sieve shaker. The weight of the initial sample and the weights retained in each sieve after $30 \mathrm{~min}$ of shaking were measured for calculating $d_{50}$ value in the cumulative distribution.

\section{X-ray diffraction (XRD) analysis}

The milled and annealed powder samples were placed in the ground glass depression in the sample holder. Afterwards, samples were flattened using a glass slide to arrange a smooth and well-packed sample. Mineral phases were identified for 20 samples using Rigaku Ultima (IV) X-ray diffractometer with $\mathrm{Cu} \mathrm{K} \alpha$ radiation. The scanning speed of $2 \theta$ (the diffraction angle of Bragg's Law) was 10.00 degree $\mathrm{min}^{-1}$ with the range of $0^{\circ}$ to $90^{\circ}$. The accelerating voltage and applied currents were $40 \mathrm{kV}$ and $30 \mathrm{~mA}$, respectively.

\section{Fourier-transform infrared (FTIR) spectroscopy}

Finely powdered samples were mixed with $\mathrm{KBr}$ in $1: 10$, and pressed into pellets for transmission. FTIR grade dried $\mathrm{KBr}$ (assay $\geq 99 \%$ ) was used as alkali halide. FTIR analysis was performed for 6 samples using a Bruker Alpha spectrophotometer to identify functional groups over the range of $500-4000 \mathrm{~cm}^{-1}$. The instrument has a resolution of $4 \mathrm{~cm}^{-1}$ over 64 scans. All individual FTIR spectra were corrected against the spectrum of $\mathrm{KBr}$ pellet and the automatic baseline. The background corrections were also carried out for the absorption of atmospheric water and $\mathrm{CO}_{2}$.

\section{X-ray fluorescence (XRF) analysis}

Loss on ignition (LOI) values (includes $\mathrm{H}_{2} \mathrm{O}, \mathrm{CO}_{2}, \mathrm{~S}$, and other volatiles) were first determined from the weight loss after heating samples at $1000{ }^{\circ} \mathrm{C}$ for $2 \mathrm{~h}$. The heavy absorber fusion technique was used to minimize the matrix effects of samples. The fusion disks were prepared by mixing a $0.75 \mathrm{~g}$ of heated sample with $9.75 \mathrm{~g}$ of a combination of lithium metaborate and lithium tetraborate with lithium bromide as a releasing agent. Samples were fused in platinum crucibles. Samples were analysed on a Panalytical Axios Advanced wavelength dispersive $\mathrm{XRF}$ at Activation Laboratories, Ontario, Canada. The intensities were then measured, and the concentrations were calculated against the standard G-16 of the Commonwealth Scientific and Industrial Research Organisation (CSIRO), Australia. In general, the limit of detection is about 0.01 wt. (\%) for most of the major elements (oxides).

\section{Results}

\section{Particle size distribution}

According to the United States Department of Agriculture (USDA) textural classification in 2012, $\mathrm{d}_{50}$ particle size distribution of initial ilmenite sample and $4 \mathrm{~h}$ milled samples are $0.14 \mathrm{~mm}$ and $0.08 \mathrm{~mm}$, respectively (Fig. 2).

\section{Investigation of ball milling and isothermal annealing by XRD}

$\mathrm{X}$-ray diffractogram of the initial sample shows peaks of ilmenite $\left(\mathrm{FeTiO}_{3}\right)$, rutile $\left(\mathrm{TiO}_{2}\right)$, and vanadium pentoxide $\left(\mathrm{V}_{2} \mathrm{O}_{5}\right)$ (Fig. 3). Vanadium pentoxide can be identified as a gangue component (Dewan et al. 2010). The diffraction peaks of ilmenite and rutile match with the standard XRD pattern of ilmenite (Joint Committee on Powder Diffraction Standards (JCPDS) card no 29-733), and rutile (JCPDS card no 21-1276). However, the initial sample contains less percentage of rutile, and their crystallinity is relatively low (Fig. 3). The major peaks corresponding to ilmenite can be observed at diffraction angles of $2 \theta=24.00^{\circ}, 26.85^{\circ}, 32.75^{\circ}, 39.65^{\circ}, 48.95^{\circ}$, $52.40^{\circ}, 63.55^{\circ}, 64.70^{\circ}$ and $83.95^{\circ}$, and that of rutile can be observed at angles of $2 \theta=35.50^{\circ}, 40.55^{\circ}$ and $54.45^{\circ}$.

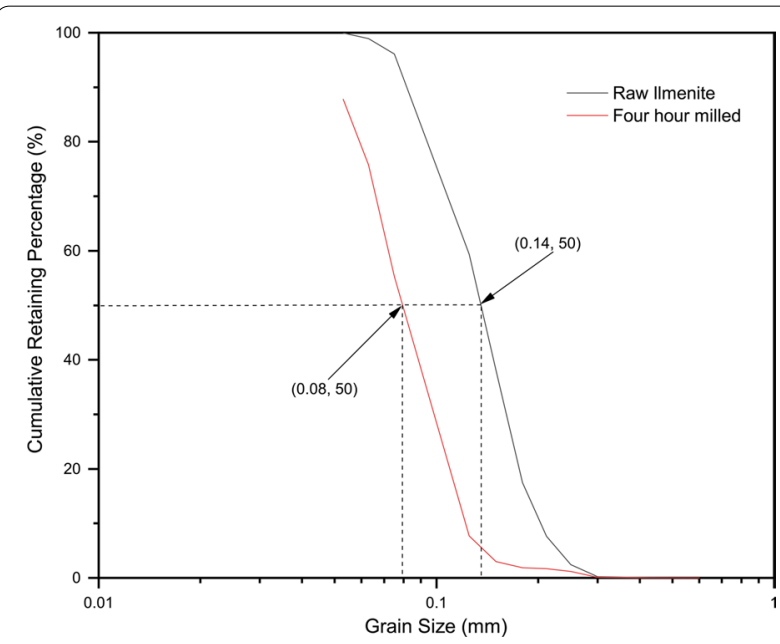

Fig. 2 Particle size distributions of initial ilmenite sample and four hours milled ilmenite sample 


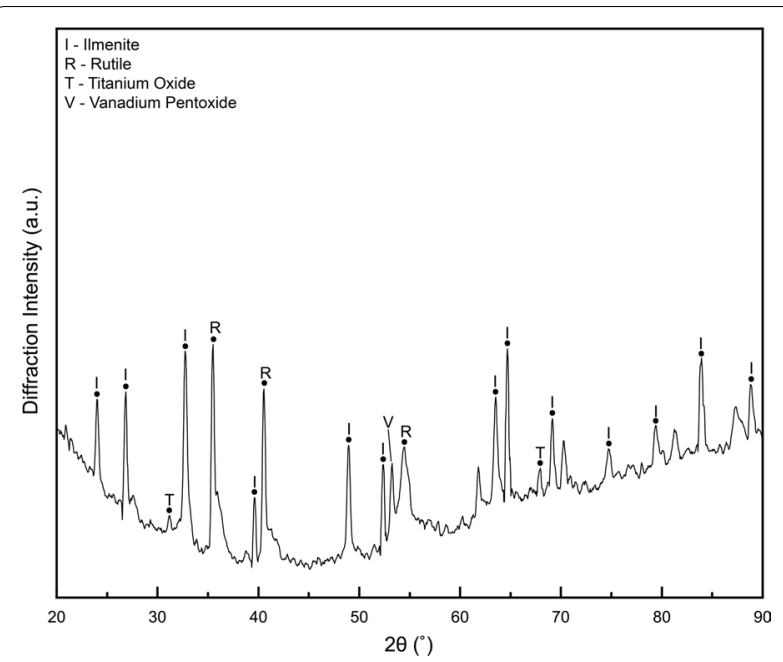

Fig. $3 \mathrm{X}$-ray diffractogram of initial ilmenite sample. Where, $\mathrm{V}$ : vanadium pentoxide $\left(\mathrm{V}_{2} \mathrm{O}_{5}\right)$, I: ilmenite $\left(\mathrm{FeTiO}_{3}\right)$, $\mathrm{R}$ : rutile $\left(\mathrm{TiO}_{2}\right)$

The XRD patterns recorded from the milled samples (annealed at $800{ }^{\circ} \mathrm{C}, 900{ }^{\circ} \mathrm{C}, 1000{ }^{\circ} \mathrm{C}, 1100{ }^{\circ} \mathrm{C}$, and $1200{ }^{\circ} \mathrm{C}$ ) are shown in Fig. 4. Sharp (crystalline) ilmenite peaks can be identified at temperatures of $800^{\circ} \mathrm{C}$ and $900{ }^{\circ} \mathrm{C}$ (Fig. 4a, b). The number of peaks corresponding to rutile is low in samples annealed at temperatures of $800{ }^{\circ} \mathrm{C}$ and $900{ }^{\circ} \mathrm{C}$, and also the respective rutile peaks are not prominent in the XRD spectra (Fig. 4a, b).

In comparison, rutile peaks are more prominent in samples annealed at $1000{ }^{\circ} \mathrm{C}$ and above (Fig. 4c-e). Consequently, the occurrence of elemental iron (indicated as $\mathrm{F}$ at $2 \theta$ of $44.57^{\circ}$ and $60.00^{\circ}$ in Fig. 4) and rutile peaks indicate the smooth progression of carbothermic reduction at $1000{ }^{\circ} \mathrm{C}$ and above. However, the remaining one or more ilmenite peaks imply that the reaction of carbothermic reduction has not been fully completed at temperatures of $1000{ }^{\circ} \mathrm{C}$ and $1100{ }^{\circ} \mathrm{C}$ (Fig. 4c, d). Although rutile peaks are prominent in the spectra of both $1000{ }^{\circ} \mathrm{C}$ and $1100{ }^{\circ} \mathrm{C}$, samples milled for 1 to $3 \mathrm{~h}$ imply lesser structural disorder in ilmenite followed by observed lower recrystallized rutile peaks after carbothermic reduction (Chen et al. 1997, 2013; Wijewardhana et al. 2021). Samples milled for $4 \mathrm{~h}$ have undergone better recrystallization of rutile with narrow and intense diffraction peaks. In addition, samples milled for $4 \mathrm{~h}$ show more rutile peaks after annealing above $1000{ }^{\circ} \mathrm{C}$ (Fig. 4d, e). Precisely, the peak intensity has increased with annealed temperature from $1000{ }^{\circ} \mathrm{C}$ to $1100{ }^{\circ} \mathrm{C}$ (Fig. 4c, d). Interestingly, all the ilmenite peaks have disappeared in the samples annealed at $1200^{\circ} \mathrm{C}$ indicating that the carbothermic reduction has been fully completed above $1100{ }^{\circ} \mathrm{C}$. However, elemental iron and rutile peaks are more prominent in samples milled for $3 \mathrm{~h}$ and $4 \mathrm{~h}$ after annealing at $1200^{\circ} \mathrm{C}$.

\section{FTIR analysis}

Figure 5 shows FTIR transmittance spectrum of the initial ilmenite sample. For example, the characteristic transmittance band for $\mathrm{CO}_{2}$ (Fig. 5) implies that atmospheric $\mathrm{CO}_{2}$ has been attached to the surface of raw ilmenite. In addition, the $\mathrm{Fe}-\mathrm{O}$ (from $520 \mathrm{~cm}^{-1}$ to $1450 \mathrm{~cm}^{-1}$ ) and Ti-O-Ti (from $550 \mathrm{~cm}^{-1}$ to $900 \mathrm{~cm}^{-1}$ ) characterises the FTIR spectrum of raw ilmenite (e.g., Chen et al. 2013; Wijewardhana et al. 2021). Furthermore, the transmittance bands around $1630 \mathrm{~cm}^{-1}$ and $3600 \mathrm{~cm}^{-1}$ can be assigned to $\mathrm{Ti}-\mathrm{OH}$ stretching and bending vibrations of hydroxyl $(\mathrm{OH})$, respectively (León et al. 2017).

Figure 6 shows FTIR spectra of $4 \mathrm{~h}$ milled samples annealed at different temperatures of $800{ }^{\circ} \mathrm{C}, 900{ }^{\circ} \mathrm{C}$, $1000{ }^{\circ} \mathrm{C}, 1100{ }^{\circ} \mathrm{C}$, and $1200{ }^{\circ} \mathrm{C}$, respectively. The broadband around $3600 \mathrm{~cm}^{-1}$ suggests the stretching vibration of the hydroxyl group (e.g., León et al. 2017). The transmittance band around $1630 \mathrm{~cm}^{-1}$ (Ti-OH vibration) appearing in all the treated samples indicates the presence of moisture during sample preparation and/ or analysis. In addition, stretching vibrations around $559 \mathrm{~cm}^{-1}$ and $586 \mathrm{~cm}^{-1}$ (attributed to $\mathrm{Fe}-\mathrm{O}$ bonds) can be observed in samples annealed below $1000{ }^{\circ} \mathrm{C}$ (Fig. 6a, b). Moreover, samples annealed above $1000{ }^{\circ} \mathrm{C}$ (Fig. 6c-e) show Ti-O-Ti stretching vibrations around $700 \mathrm{~cm}^{-1}$ (Siddick et al. 2018; Wijewardhana et al. 2021).

\section{XRF analysis}

Table 2 shows the chemical compositions of raw and treated ilmenite samples. Raw ilmenite concentrate is characterised by over 93 wt.\% of $\mathrm{FeOTiO}_{2}, \sim 4 \mathrm{wt} . \%$ of $\mathrm{SiO}_{2}, \sim 1$ wt.\% of $\mathrm{Al}_{2} \mathrm{O}_{3}$, and the rest compensated by other minor oxides. $\mathrm{TiO}_{2}$ and $\mathrm{TiO}_{2}+\mathrm{Fe}_{2} \mathrm{O}_{3}$ (total) variations of annealed samples suggest that carbothermic reduction can be enhanced after annealing above $1000{ }^{\circ} \mathrm{C}$ (Table 2).

\section{Discussion}

In this study, a mixture of ilmenite and activated carbon was milled for 1 to $4 \mathrm{~h}$ to investigate the possible beneficial effects of milling on carbothermic reduction of ilmenite. Particle size changes, and the effect of particle size on annealing were compared with the initial sample to determine the effective number of milling hours. Accordingly, $4 \mathrm{~h}$ milled sample was observed to be laid at a very fine sand region of the USDA textural classification. Mechanical attrition during milling enhances the surface area, energy transferring and lattice distortions of materials (Tao et al. 2012). Moreover, carbon can be incorporated into the ilmenite structure through weak crystallographic planes (Wijewardhana et al. 2021). 
(a) Annealed Temperature $\left(800^{\circ} \mathrm{C}\right)$

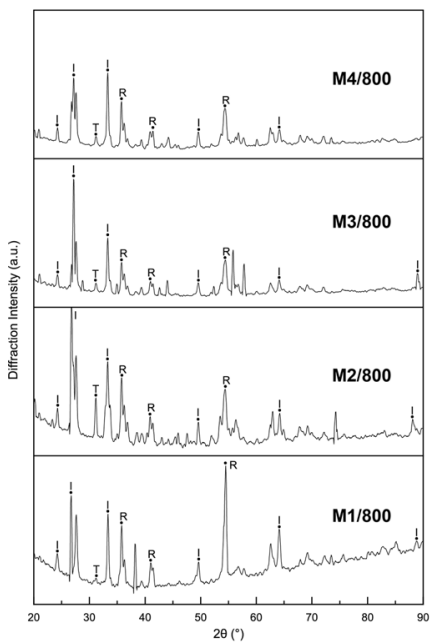

(b) Annealed Temperature $\left(900^{\circ} \mathrm{C}\right)$

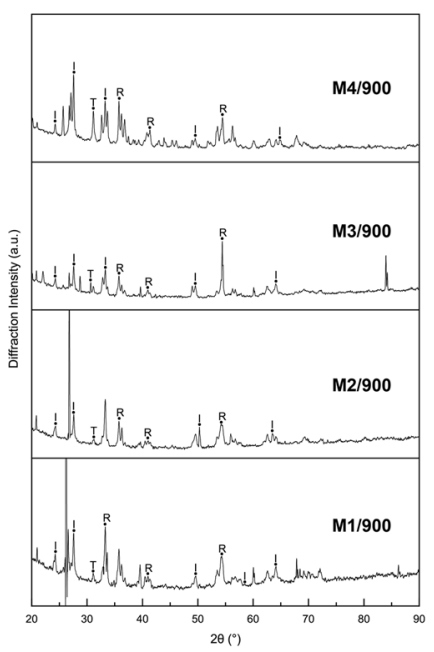

(c) Annealed Temperature $\left(1000^{\circ} \mathrm{C}\right)$

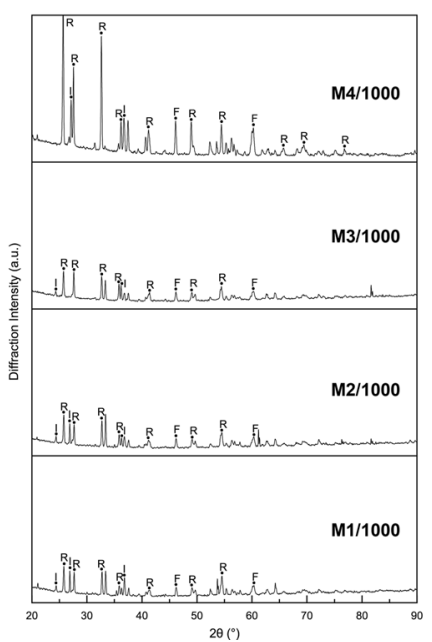

(d) Annealed Temperature $\left(1100^{\circ} \mathrm{C}\right)$

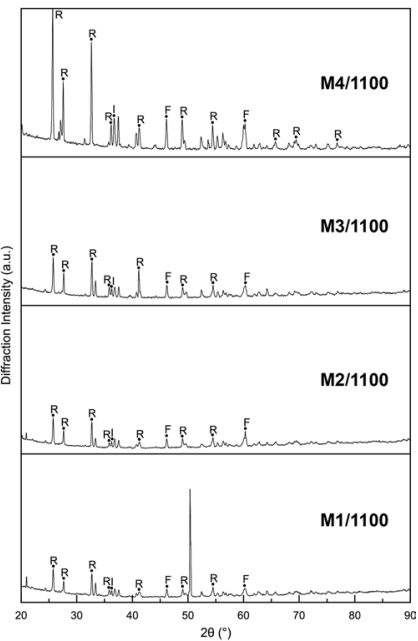

(e) Annealed Temperature $\left(1200^{\circ} \mathrm{C}\right)$

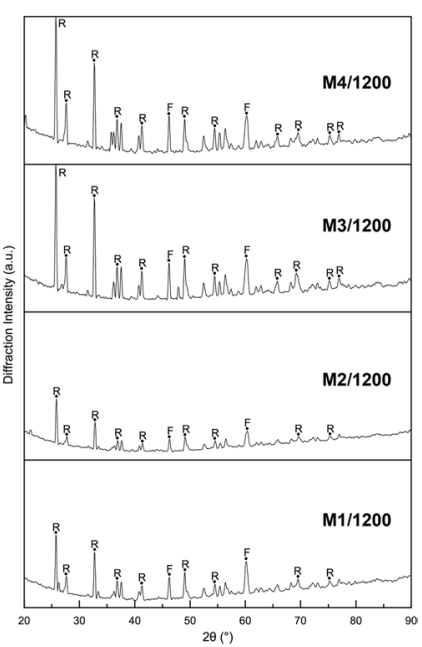




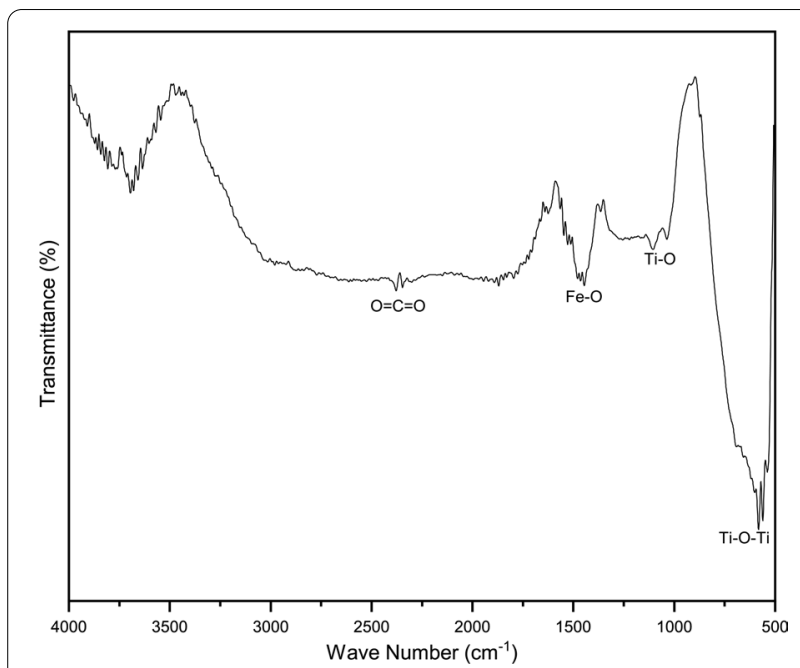

Fig. 5 FTIR spectrum of the initial ilmenite sample showing characteristic bonds

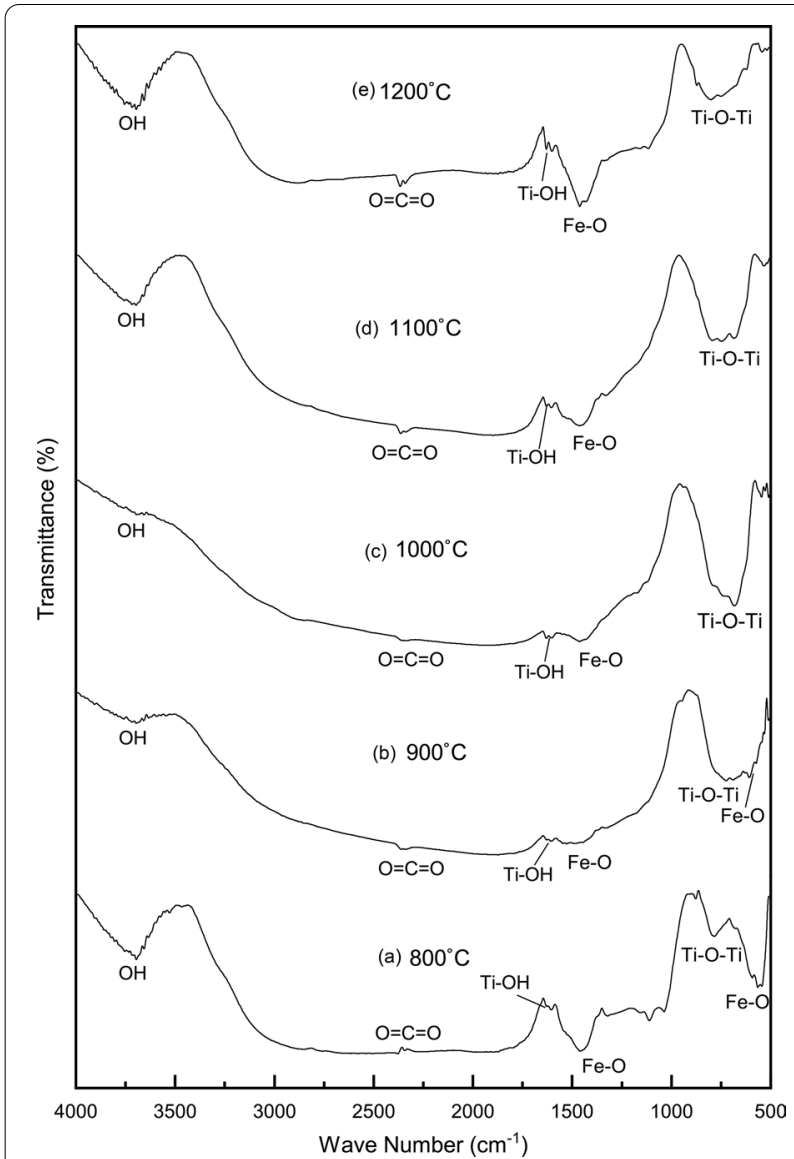

Fig. 6 FTIR spectra of $4 \mathrm{~h}$ milled ilmenite samples (a) annealed at $800^{\circ} \mathrm{C},(\mathbf{b})$ annealed at $900^{\circ} \mathrm{C},(\mathbf{c})$ annealed at $1000^{\circ} \mathrm{C},(\mathbf{d})$ annealed at $1100^{\circ} \mathrm{C}$, and (e) annealed at $1200^{\circ} \mathrm{C}$
The recorded XRD pattern suggests that the energy required for completing the carbothermic reduction of ilmenite into synthetic rutile is not sufficient at temperatures of $800{ }^{\circ} \mathrm{C}$ and $900{ }^{\circ} \mathrm{C}$. Carbothermic reduction reaction is almost completed at the temperature of $1000{ }^{\circ} \mathrm{C}$ and $1100{ }^{\circ} \mathrm{C}$, and fully completed at the temperature of $1200^{\circ} \mathrm{C}$. Notably, the increment of intensity and the number of rutile peaks in the samples annealed at $1000{ }^{\circ} \mathrm{C}, 1100{ }^{\circ} \mathrm{C}$ and $1200{ }^{\circ} \mathrm{C}$ suggest that the crystallinity and $\mathrm{TiO}_{2}$ phase have increased, with a well-crystallised structure. Consequently, defects and disorders during mechanical activation have been cured during annealing at high temperatures. However, $3 \mathrm{~h}$ of ball milling is sufficient for the complete carbothermic reduction of ilmenite at $1200{ }^{\circ} \mathrm{C}$ (Fig. 4e). Nevertheless, milling for $3 \mathrm{~h}$ and annealing at $1200{ }^{\circ} \mathrm{C}$, and milling for $4 \mathrm{~h}$ and annealing at $1000{ }^{\circ} \mathrm{C}$ show similar results (Fig. 4c, e). Thus, the additional 1-h of milling would be efficient than rising and maintaining the temperature at $1200{ }^{\circ} \mathrm{C}$ for $2 \mathrm{~h}$ (Fig. 4c, e). The energy requirement is high to elevate the annealing temperature at $1200{ }^{\circ} \mathrm{C}$ than milling for an additional hour. Consequently, annealing at $1200{ }^{\circ} \mathrm{C}$ is less feasible due to high power prices in Sri Lanka (Subasinghe et al. 2021).

FTIR spectroscopy can be used for qualitative analysis of compounds, providing specific details on molecular structure, chemical bonding, and molecular environment (Zhang et al. 2011; Ramalla et al. 2015; León et al. 2017). Therefore, FTIR results suggest that ilmenite undergoes carbothermic reduction with activated carbon at temperatures above $1000{ }^{\circ} \mathrm{C}$. In this regard, it is evident that $\mathrm{Fe}-\mathrm{O}$ bond in ilmenite is broken, and new Ti-O bonds are formed subsequently during carbothermic reduction at $1000{ }^{\circ} \mathrm{C}$ and above.

In XRF analysis, all annealed samples were reheated at $1000{ }^{\circ} \mathrm{C}$ for $2 \mathrm{~h}$ to determine LOI values. Consequently, $\mathrm{XRF}$ results provide limited information for quantifying phase transition from ilmenite to synthetic rutile under low annealed $\left(800{ }^{\circ} \mathrm{C}\right.$ and $\left.900{ }^{\circ} \mathrm{C}\right)$ temperatures.

Mechanical incorporation of reductants into ilmenite effectively enhances carbothermic reduction due to increment of effective surface area, reduction of crystallite size within individual particles, extension of crystal defects, and alteration of lattice distortions (Chen et al. 1997; Sasikumar et al. 2004; Tao et al. 2012; Low et al. 2017; Wijewardhana et al. 2021). Consequently, mechanical activation via ball milling increases the homogeneity of the mixture and thus lessens diffusion (Welham and Williams 1999).

The chemical reactions occurring in this reduction process are shown below. 


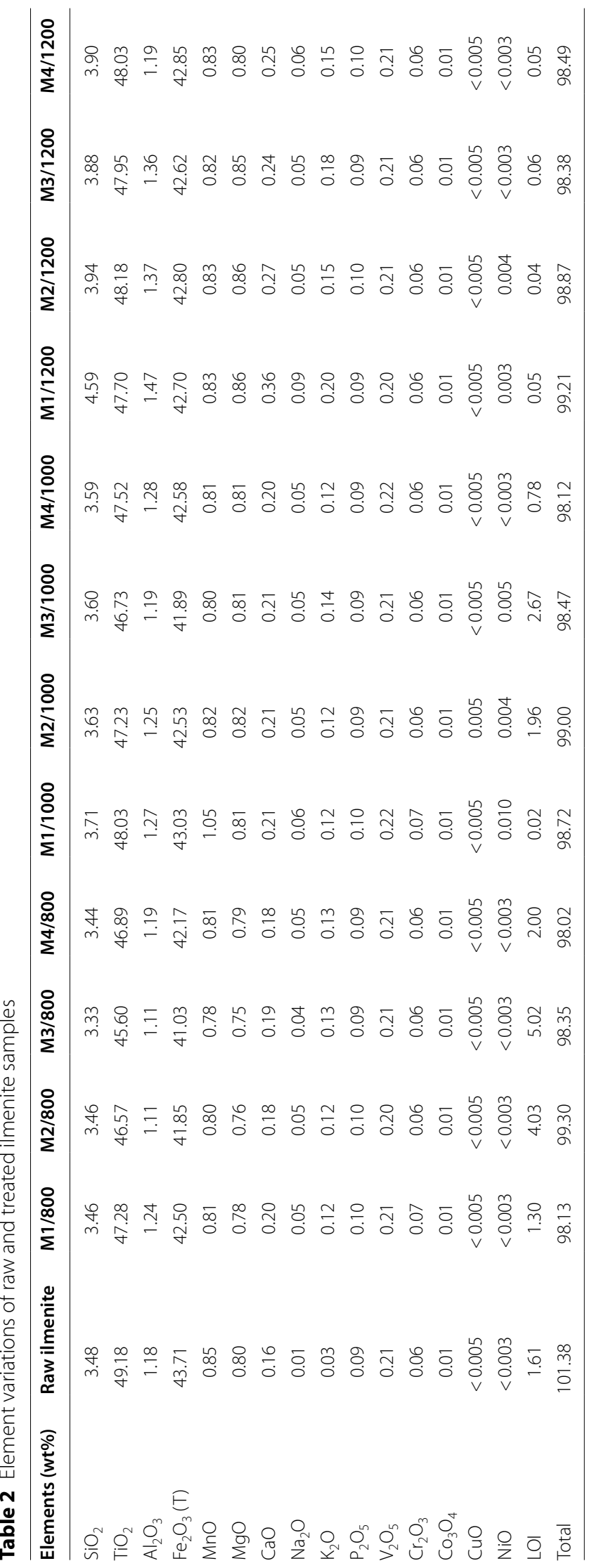




$$
\begin{aligned}
& \mathrm{FeTiO}_{3}(\mathrm{~s})+\mathrm{C}(\mathrm{s}) \rightarrow \mathrm{Fe}(\mathrm{s})+\mathrm{TiO}_{2}(\mathrm{~s}) \\
& +\mathrm{CO}(\mathrm{g}) \text { solid }- \text { solid reaction } \\
& \mathrm{C}(\mathrm{s})+\mathrm{CO}_{2}(\mathrm{~g}) \rightarrow 2 \mathrm{CO}(\mathrm{g}) \text { solid }- \text { gas reaction } \\
& \mathrm{FeTiO}_{3}(\mathrm{~s})+\mathrm{CO}(\mathrm{g}) \rightarrow \mathrm{Fe}(\mathrm{s})+\mathrm{TiO}_{2}(\mathrm{~s}) \\
& +\mathrm{CO}_{2}(\mathrm{~g}) \text { solid }- \text { gas reaction }
\end{aligned}
$$

The reactions denoted by Eq. 1 is a solid-state reduction reaction (Welham 1996; Chen et al. 1997) and that of Eq. 2 is a solid-gas reaction where carbon dioxide $\left(\mathrm{CO}_{2}\right)$ produced reacts with the remaining hot carbon to produce $\mathrm{CO}$ at high temperatures (Wouterlood 1979; Chen et al. 1997). In this regard, it is evident that the carbothermic reduction of ilmenite concentrates depends on temperature (Gupta et al. 1989; Wang and Yuan 2006). The optimum conditions of these reactions can also be controlled by physical and chemical characteristics and mineralogical composition of ilmenite ores (Ismail et al. 1983; Welham and William 1999; Wang and Yuan 2006). For example, the presence of manganese $(\mathrm{Mn})$ above $1.24 \mathrm{wt} \%$ reduces the rate of carbothermic reduction of ilmenite (Wang and Yuan 2006; Wang et al. 2008). Literature ( 0.95 wt.\%, Herath 1980; Ismail et al. 1983) and XRF analysis of the present experiment ( $0.85 \mathrm{wt} \%$, Table 2 ) prove the applicability of carbothermic reduction for ilmenite ores in Sri Lanka. This method can thus be identified as an industrially important process due to the solid-state separation of titanium dioxide (synthetic rutile) and iron present in ilmenite (Zhao and Shadman 1991). In this method, a magnetic separation followed by a simple leaching step is required to purify the synthetic rutile produced (Ismail et al. 1983; Sasikumar et al. 2004; Adipuri et al. 2011; Tao et al. 2012). Consequently, carbothermic reduction can be employed to upgrade the ilmenite resources in Sri Lanka and uplift the mineral processing industry.

\section{Conclusions}

The particle size distribution of the mixture of Sri Lankan ilmenite and commercially available activated carbon suggested a significant reduction of grain size after $4 \mathrm{~h}$ of ball milling $\left(\mathrm{d}_{50}=0.08 \mathrm{~mm}\right)$. Although milling is considered as an essential process for particle size reduction and to maintain homogeneity of the mixture, any direct evidence of carbothermic reduction was not recorded during the process of ball milling. However, XRD observations (i.e., more rutile peaks and increased crystallinity) suggested that carbothermic reduction has been completed by decomposition of ilmenite into elemental iron and $\mathrm{TiO}_{2}$ after milling for $4 \mathrm{~h}$ and isothermal annealing at $1000{ }^{\circ} \mathrm{C}$ and above continuously for $2 \mathrm{~h}$. Similarly, $\mathrm{Ti}-\mathrm{O}-\mathrm{Ti}$ stretching vibrations around $700 \mathrm{~cm}^{-1}$ and $\mathrm{TiO}_{2} / \mathrm{TiO}_{2}+\mathrm{Fe}_{2} \mathrm{O}_{3}$ (total) variations suggest sufficient energy for carbothermic reduction at $1000{ }^{\circ} \mathrm{C}$, despite a negligible amount of remaining ilmenite which can be easily decomposed by fine-tuning the timing of thermal treatment. Therefore, ball milling induced carbothermic reduction is applicable to produce a mixture of rutile and elemental iron from ilmenite at the optimum conditions of 4-h milling and annealing at $1000^{\circ} \mathrm{C}$ for $2 \mathrm{~h}$. However, magnetic separation followed by a simple leaching process would be encountered to purify the synthetic rutile produced by this mechanochemical method. Consequently, this method has the potential to be established for Sri Lankan ilmenite ores.

\section{Abbreviations \\ XRD: X-ray diffraction; FTIR: Fourier-transform infrared; XRF: X-ray fluorescence; LOI: Loss on ignition; CSIRO: Commonwealth Scientific and Industrial Research Organisation; USDA: United States Department of Agriculture; JCPDS: Joint Committee on Powder Diffraction Standards.}

\section{Acknowledgements}

We would like to thank Lanka Mineral Sands Limited, Pulmoddai for providing samples and necessary information. We also wish to extend our gratitude to M.D. Nilantha, Sandun Wijerama and Pradeep Ranathunga for assisting in geochemical laboratory work at Uva Wellassa University, Sri Lanka. Niroshan Seneviratne (Uva Wellassa University), and Kalana Dissanayake (Senior Lab Executive, Lanka Minerals and Chemicals) are also acknowledged for giving fullest cooperation.

\section{Authors' contributions}

ASR obtained the research grant for this project, conceived of the presented idea, verified the analytical methods, and supervised TDUW. The first author carried out the experiments, designed the theory of the project, performed the experimental calculations, and interpreted the results. All authors analysed and discussed results, provided critical feedback, and contributed to the final manuscript. All authors read and approved the final manuscript.

\section{Funding}

This research was supported by the Accelerating Higher Education Expansion and Development (AHEAD) Operation of the Ministry of Higher Education funded by the World Bank.

Availability of data and materials

The data that support the findings of this study are available within this article.

\section{Declarations}

Ethics approval and consent to participate

Not applicable.

\section{Consent for publication \\ Not applicable.}

\section{Competing interests}

On behalf of all authors, the corresponding author states that there is no conflict of interest.

Received: 17 May 2021 Accepted: 16 August 2021

Published online: 23 August 2021 


\section{References}

Adipuri A, LiY, Zhang G, Ostrovski O (2011) Chlorination of reduced ilmenite concentrates and synthetic rutile. Int J Miner Process 100:166-171. https:// doi.org/10.1016/j.minpro.2011.07.005

Amalan K, Ratnayake AS, Ratnayake NP, Weththasinghe SM, Dushyantha N, Lakmali N, Premasiri R (2018) Influence of nearshore sediment dynamics on the distribution of heavy mineral placer deposits in Sri Lanka. Environ Earth Sci 77:737. https://doi.org/10.1007/s12665-018-7914-4

Angusamy N, Sahayam DJ, Gandhi SM, Rajamanickam GV (2005) Coastal placer deposits of central Tamil Nadu, India. Mar Georesources Geotechnol 23(3):137-174. https://doi.org/10.1080/10641190500192102

Chen G, Song Z, Chen J, Peng J, Srinivasakannan C (2013) Evaluation of the reducing product of carbonthermal reduction of ilmenite ores. J Alloys Compd 577:610-614. https://doi.org/10.1016/j.jallcom.2013.06.038

Chen Y, Hwang T, Marsh M, Williams JS (1997) Mechanically activated carbothermic reduction of ilmenite. Metall Mater Trans A 28:1115-1121. https://doi.org/10. 1007/s11661-997-0277-1

Dewan MA, Zhang G, Ostrovski O (2010) Carbothermal reduction of a primary ilmenite concentrate in different gas atmospheres. Metall Mater Trans B 41 (8):182-192. https://doi.org/10.1007/s11663-009-9308-1

Dooley GJ (1975) Titanium production: ilmenite vs. rutile. JOM 27:8-16. https://doi. org/10.1007/BF03355886

Geological Survey of Ceylon. Beach mineral sands and silicon sands of Ceylonpamphlet. Geological Survey and Mines Bureau, Colombo, Sri Lanka. http:// www.gsmb.gov.lk/web/index.php?option $=$ com_content\&view=article\& $i \mathrm{~d}=155 \&$ ltemid $=98 \&$ lang $=$ en (1970). Accessed 18 Mar 2021

Gupta SK, Rajakumar V, Grieveson P (1989) The influence of weathering on the reduction of ilmenite with carbon. Metall Mater Trans B 20:735-745. https:// doi.org/10.1007/BF02655932

Herath JW (1980) Mineral resources of Sri Lanka. 2nd revised edn. Economic Bullein. No. 2

Ismail MGMU, Amarasekara J, Kumarasinghe JSN (1983) The upgrading of ilmenite from Sri Lanka by the oxidation-reduction-leach process. Int J Miner Process 10:161-164

Kahn JA (1984) Non-rutile feedstocks for the production of titanium. J Miner Metals Mater Soc 36(7):33-38. https://doi.org/10.1007/BF03338498

Lanka Mineral Sands Ltd. Company profile. Lanka Mineral Sands Ltd, Colombo, Sri Lanka. http://www.lankamineralsands.com/ (2018). Accessed 10 Jan 2021.

Lee CT, Sohn HY (1989) Recovery of synthetic rutile and iron oxide from ilmenite ore by sulfation with ammonium sulphate. Ind Eng Chem Res 28:1802-1808. https://doi.org/10.1021/ie00096a011

León A, Reuquen P, Garín C, Segura R, Vargas P, Zapata P, Orihuela P (2017) FTIR and Raman characterization of $\mathrm{TiO}_{2}$ nanoparticles coated with polyethylene glycol as carrier for 2-methoxyestradiol. Appl Sci 7(1):49. https://doi.org/10. 3390/app7010049

Low FW, Lai CW, Abd Hamid SB (2017) Study of reduced graphene oxide film incorporated of $\mathrm{TiO}_{2}$ species for efficient visible light driven dye-sensitized solar cell. J Mater Sci: Mater Electron 28(1):3819-3836. https://doi.org/10. 1007/s10854-016-5993-0

Mackey TS (1994) Upgrading ilmenite in to high-grade synthetic rutile. JOM 46:59-64. https://doi.org/10.1007/BF03220676

Mahmoud MHH, Afifi AA, Ibarhim IA (2004) Reductive leaching of ilmenite ore in hydrochloric acid for preparation of synthetic rutile. Hydrometallurgy 73:99-109. https://doi.org/10.1016/j.hydromet.2003.08.001

Murty CVGK, Upadhyay R, Asokan S (2007) Electro smelting of ilmenite for production of $\mathrm{TiO}_{2}$ slag-potential of India as a global player. In: Proceedings of Infacon XI, India, pp 18-21

Neurgaonkar VG, Gokarn AN, Joseph K (1986) Beneficiation of ilmenite to rutile by selective chlorination in a fluidised bed. J Chem Technol Biotechnol 36:27-30. https://doi.org/10.1002/jctb.280360105

Nurdin M, Maulidiyah WAH, Abdillah N, Wibowo D (2019) Development of extraction method and characterization of $\mathrm{TiO}_{2}$ mineral from ilmenite. Int J Chem Technol Res 9:483-491

Palliyaguru L, Arachchi NDH, Jayaweera CD, Jayaweera PM (2017) Production of synthetic rutile from ilmenite via anion-exchange. Miner Process Extr Metall 127(3):169-175. https://doi.org/10.1080/03719553.2017.1331621

Perks C, Mudd G (2020) A detailed assessment of global Zr and Ti production. Miner Econ. https://doi.org/10.1007/s13563-020-00240-5

Perks C, Mudd G (2021) Soft rocks, hard rocks: the world's resources and reserves of Ti and Zr and associated critical minerals. Int Geol Rev. https://doi.org/10. 1080/00206814.2021.1904294
Perks C, Mudd G (2019) Titanium, zirconium resources and production: a state of the art literature review. Ore Geol Rev 107:629-646. https://doi.org/10.1016/j. oregeorev.2019.02.025

Ramalla I, Gupta RK, Bansal K (2015) Effect on superhydrophobic surfaces on electrical porcelain insulator, improved technique at polluted areas for longer life and reliability. Int J Eng Technol 4(4):509-519

Rhee Kl, Sohn HY (1990) The selective carbochlorination of iron from titanlferous magnetite ore in a fluidized bed. Metall Mater Trans B 21:341-347. https://doi. org/10.1007/BF02664202

Sasikumar C, Rao DS, Srikanth S, Ravikumar B, Mukhopadhyay NK, Mehrotra SP (2004) Effect of mechanical activation on the kinetics of sulphuric acid leaching of beach sand ilmenite from Orissa, India. Hydrometallurgy 75:189-204. https://doi.org/10.1016/j.hydromet.2004.08.001

Shahien MG, Khedr MMH, Maurice AE, Farghali AA, Ali RAM (2015) Synthesis of high purity rutile nanoparticles from medium-grade Egyptian natural ilmenite. Beni-Suef Univ J Basic Appl 4:207-213. https://doi.org/10.1016/j. bjbas.2015.05.013

Shiah CD (1978) U.S. Patent No. 4,085,190. U.S. Patent and Trademark Office, Washington, DC

Siddick SZ, Lai CW, Juan JC (2018) An investigation of the dye-sensitized solar cell performance using graphene-titania ( $T r G O)$ photoanode with conventional dye and natural green chlorophyll dye. Mater Sci Semicond Process 74:267-276. https://doi.org/10.1016/j.mssp.2017.10.046

Sri Lanka Minerals Year Book (2014) Geological survey and Mines Bureau, Colombo, Sri Lanka. ISBN 978-955-9323-75-4

Subasinghe HCS, Ratnayake AS, Sameera KAG (2021) State-of-the-art and perspectives in the heavy mineral industry of Sri Lanka. Miner Econ. https://doi.org/ 10.1007/s13563-021-00274-3

Tao T, Chen QY, Hu HP, Yin ZL, Chen Y (2012) TiO 2 nanoparticles prepared by hydrochloric acid leaching of mechanically activated and carbothermic reduced ilmenite. Trans Nonferrous Met Soc China 22:1232-1238. https://doi.org/10. 1016/S1003-6326(11)61310-1

United States Department of Agriculture (2012) National engineering handbook: engineering classification of earth materials. https://directives.sc.egov.usda. gov/OpenNonWebContent.aspx?content=31847.wb. Accessed 10 Jan 2021

Wang Y, Yuan Z (2006) Reductive kinetics of the reaction between a natural ilmenite and carbon. Int J Miner Process 81:133-140. https://doi.org/10.1016/j. minpro.2006.07.010

Wang YM, Yuan ZF, Guo ZC, Tan QQ, Li ZY (2008) Reduction mechanism of natural ilmenite with graphite. Trans Nonferrous Met Soc China 18:962-968. https:// doi.org/10.1016/S1003-6326(08)60166-1

Welham NJ, Williams JS (1999) Carbothermic reduction of ilmenite $\left(\mathrm{FeTiO}_{3}\right)$ and rutile $\left(\mathrm{TiO}_{2}\right)$. Metall Mater Trans B 30:1075-1081. https://doi.org/10.1007/ s11663-999-0113-7

Welham NJ (1996) A parametric study of the mechanically activated carbothermic reduction of ilmenite. Miner Eng 9:1189-1200. https://doi.org/10.1016/ S0892-6875(96)00115-X

Wickremeratne WS (1986) Preliminary studies on the offshore occurrences of monazite-bearing heavy-mineral placers, southwestern Sri Lanka. Mar Geol 72:1-9. https://doi.org/10.1016/0025-3227(86)90095-2

Wijewardhana TDU, Subasinghe HCS, Ratnayake AS. Value addition to ilmenite using carbonized waste coconut shells: a mechanochemical approach aided with powdered seashells as a rate raiser. Mining Metall Explor. doi: https://doi. org/10.1007/s42461-021-00420-z

Wouterlood HJ (1979) The reduction of ilmenite with carbon. J Chem Technol Biotechnol 29:603-618. https://doi.org/10.1002/jctb.503291002

Wright JB, Elger GW, Tress JE, Bell HE (1985) Chlorination-grade feedstock from domestic ilmenite. Min Metall Explor 2:198-202. https://doi.org/10.1007/ BF03402619

Zhang W, Zhu Z, Cheng CY (2011) A literature review of titanium metallurgical processes. Hydrometallurgy 108:177-188. https://doi.org/10.1016/j.hydro met.2011.04.005

Zhao Y, Shadman F (1991) Reduction of ilmenite with hydrogen. Ind Eng Chem Res 30:2080-2087. https://doi.org/10.1021/ie00057a005

\section{Publisher's Note}

Springer Nature remains neutral with regard to jurisdictional claims in published maps and institutional affiliations. 